\title{
Using Opioid Settlement Proceeds for Public Health: Lessons from the Tobacco Experience
}

\author{
Micah L. Berman*
}

State, county, and city governments across the country have filed hundreds of lawsuits against opioid manufacturers, distributors, and retailers. The odds are high that these lawsuits will culminate in a "global settlement agreement" that requires the defendants to pay billions of dollars to states and localities that have been harmed by the opioid epidemic. Though much of that money will-and should-be spent to reimburse communities for opioid-related costs they have already incurred, such a settlement would also provide a tremendous opportunity to strengthen the nation's public health system infrastructure in order to better protect against future public health challenges. The experience of the 1998 Master Settlement Agreement (MSA) with the major tobacco companies, however, suggests that setting aside funds for public health will not be easy. This article reviews the history of how states spent their MSA funds, with a focus on the efforts of public health advocates to ensure that some portion of the funds were spent on tobacco prevention and cessation. These efforts were, in many cases, successful in the short term, but they were not sustained over time. This article will summarize lessons learned from the MSA experience that can be applied to a potential opioid settlement agreement.

\section{INTRODUCTION}

Whenever a new state or locality files a lawsuit against opioid manufacturers and distributors, commentators and journalists inevitably mention the parallels to the states' litigation against the tobacco industry

\footnotetext{
* Associate Professor of Public Health and Law, The Ohio State University. Thanks to Wendy Parmet, Lance Gable, Elizabeth Weeks, and all of the participants at the 2018 Kansas Law Review Symposium and the 2019 "Rethink Opioids" conference at American University. Thanks as well to Zain Bali and Rhianna Wardian for their research assistance.
} 
in the 1990s. ${ }^{1}$ The latter litigation culminated in the 1998 Master Settlement Agreement (MSA) between forty-six states and the major cigarette companies, which imposed numerous restrictions on tobacco industry conduct and also mandated massive payments from the tobacco companies to the settling states - more than \$200 billion over the first twenty-five years of the agreement. ${ }^{2}$

Although the MSA funds were intended in part to reimburse the states for money already spent to cover smoking-related medical expenses, the attorneys general who signed the MSA made it clear that a major goal of the agreement was to fund public health efforts that would help current smokers to quit and prevent kids from starting to smoke. ${ }^{3}$ In one typical example, Oregon Attorney General Hardy Myers said, "I am hoping that [the governor] and lawmakers, understanding the direct link between tobacco use and increased health care costs, will invest the proceeds in health care, namely, smoking cessation and prevention programs and increased access to health care." 4

In the current opioid litigation, the public officials bringing these lawsuits and the outside counsel working with them have been making similar statements about their intentions. ${ }^{5}$ For instance, Mike Moore, who

\footnotetext{
1. See, e.g., Jacob Gershman, Ohio Opioid Suit Echoes Tobacco Cases, Wall. St. J. (May 31, 2017), https://www.wsj.com/articles/ohio-opioid-suit-echoes-tobacco-cases-1496275673 [https://perma.cc/SZE5-CJB7]; Casey McDermott, In N.H. Opioid Lawsuit, Echoers of Past Battles Against Tobacco, Other Industries, N.H. PUB. RADIO (Aug. 11, 2017), https://www.nhpr.org/post/nhopioid-lawsuit-echoes-past-battles-against-tobacco-other-industries\#stream/0 [https://perma.cc/ TYT4-9N5U]; John Pacenti, Opioid Crisis: Cities, States Use Tobacco Playbook to Sue Big Pharma, PALM BEACH POST (May 25, 2018), https://www.palmbeachpost.com/news/crime-law/opioidcrisis-cities-states-use-tobacco-playbook-sue-big-pharma/rQReMHP7Ezgqa8h7YMb19H/

[https://perma.cc/4FHF-D4NU]. In some cases, the lawsuits themselves have explicitly referenced the tobacco industry. See Complaint at 18, Ohio v. Purdue Pharma L.P., et al., No. 17-CI-261 (Ross Cnty. Ct. of C.P. May 31, 2017), https://www.ohioattorneygeneral.gov/Files/Briefing-Room/NewsReleases/Consumer-Protection/2017-05-31-Final-Complaint-with-Sig-Page.aspx [https://perma.cc/ C3YQ-EM8U] (alleging that "[1]ike the tobacco companies, Defendants used third parties that they funded, directed, and controlled to carry out and conceal their scheme to deceive doctors and patients about the risks and benefits of long-term opioid use for chronic pain.").

2. See National Association of Attorneys General, Master Settlement Agreement (1998), https://www.naag.org/assets/redesign/files/msa-tobacco/MSA.pdf $\quad$ [https://perma.cc/6PJJ-XLJ7] [hereinafter MSA].

3. See Campaign for Tobacco-Free Kids, Using Tobacco Settlement funds for Tobacco Prevention: Supportive Quotes from High-Ranking State Officials (Jan. 22, 1999), https://www.tobaccofreekids.org/assets/factsheets/0120.pdf [ [https://perma.cc/WQF5-2ETX] (collecting quotes).

4. Id. at 6 .

5. See, e.g., Brian Mann, Opioid-Makers Face Wave of Lawsuits in 2019, NAT'L. PUB. RAdIO (Dec. 31, 2018), https://www.npr.org/2018/12/31/680741170/opioid-makers-face-wave-of-lawsuitsin-2019 [https://perma.cc/P7NM-VASL] ("Local and state officials say they desperately need [an MSA-like] cash settlement to solve this crisis .... A settlement worth tens of billions of dollars could revolutionize the national response, creating more drug rehab programs, detox beds, and more training
} 
filed the first state lawsuit against the tobacco industry as Mississippi Attorney General and is now, as an attorney in private practice, helping to coordinate opioid litigation for the plaintiff states and localities, recently said, "We cannot fail in making sure whatever dollars we get in a resolution go to treatment and emergency response and education."

But despite the stated intentions of those involved in the tobacco litigation, only a small percentage of the MSA proceeds has gone towards tobacco prevention and cessation. As summarized in a recent Politico article:

Only a pittance of the billions in tobacco company payouts has been spent on combating tobacco use. Instead, much of the money, which the industry continues to pay out, is plowed into state slush funds and used to patch budget shortfalls. In the most extreme cases, states sacrificed future payments for much smaller, but immediate infusions of cash to pay workers, or build schools and roads. ${ }^{7}$

The Campaign for Tobacco-Free Kids estimates that since the payments began, states have spent only $2.6 \%$ of their revenue from the MSA and tobacco taxes on tobacco-related programming. ${ }^{8}$

As the opioid litigation moves towards what many predict will be a massive "global settlement" that resolves most of the cases brought by governmental entities, ${ }^{9}$ this article looks back at what happened to the

for first responders."')

6. Paul Demko, Opioid Court Fights Risk Repeating Tobacco's Failures, POLITICO (May 24, 2018), https://www.politico.com/story/2018/05/24/opioids-epidemic-tobacco-607119 [https://perma.cc/LH8R-ZQH2] (additionally quoting Connecticut's chief deputy attorney general as saying, "We think it's incumbent upon all of us to get a reasonable deal that bends the curve on the crisis"). Moore also recently said, "Success for me would be that we would find funding to provide treatment for all the 2.5 million opioid-dependent people in the country." Bill Whitaker, Opioid Crisis: The Lawsuits That Could Bankrupt Manufacturers and Distributors, CBS NEws (Dec. 16, 2018), https://www.cbsnews.com/news/opioid-crisis-attorney-mike-moore-takes-on-manufacturersand-distributors-at-the-center-of-the-epidemic-60-minutes/ [https://perma.cc/9PP3-ALJR].

7. Demko, supra note 6.

8. Matthew L. Myers, On the $20^{\text {th }}$ Anniversary of the State Tobacco Settlement (The MSA), It's Time for Bold Action to Finish the Fight Against Tobacco, CAMPAIGN FOR TOBACCO-FrEE KIDS (Nov. 26, 2018), https://www.tobaccofreekids.org/press-releases/2018_11_26_msa20

[https://perma.cc/9G6T-H275]. This amount includes both MSA payments and revenue from tobacco taxes. In most cases, both types of funds are placed into a general revenue fund and then a legislative appropriation is made for tobacco control efforts, so it is impossible to determine what is being spent from MSA funds as opposed to tax revenue. The 2.6\% figure equates to approximately $\$ 11.1$ billion spent on state tobacco prevention and cessation efforts since FY (Fiscal Year) 2000. To place that amount in context, the tobacco industry spent $\$ 9.5$ billion in 2016 alone on marketing its products in the United States. See Tobacco Industry Marketing, CTRS. FOR DisEASE CONTROL AND PREVENTION, https://www.cdc.gov/tobacco/data_statistics/fact_sheets/tobacco_industry/marketing/index.htm [https://perma.cc/TD24-4F7X] (last visited Apr. 2, 2019).

9. See Jan Hoffman, Opioid Lawsuits are Headed to Trial. Here's Why the Stakes Are Getting 
MSA settlement funds. It then considers whether the (generally unsuccessful) efforts to ensure that MSA proceeds were used to advance public health provide lessons that can inform any future settlements with opioid manufacturers and distributors. Part I provides a brief overview of the current litigation against opioid-related companies and the past litigation against the tobacco industry. Next, Part II discusses the MSA, focusing on the states' allocation of settlement proceeds and the role the non-governmental tobacco prevention foundation established as part of the settlement agreement. Part III concludes the article with a discussion of how proceeds from an opioid settlement agreement might be better protected against diversion away from their intended purpose. ${ }^{10}$

\section{THE TOBACCO AND OPIOID LAWSUITS}

Against the background of decades of largely failed attempts by individual smokers to hold the tobacco industry liable in court, state attorneys general attempted a new tactic. " "In essence, the states' legal theories, which later came to include statutorily based claims, such as violation of consumer protection laws, asserted that the industry's deceptive and misleading conduct constituted a wrong against the public." $" 12$ In other words, the states alleged that they were being forced to pay smoking-related health care costs that should properly be the

Uglier, N.Y. TIMES (Jan. 30, 2019), https://www.nytimes.com/2019/01/30/health/opioid-lawsuitssettlement-trial.html [https://perma.cc/J7PD-XZ74] ("The defendants want a global settlement-a comprehensive agreement that will indemnify them against further lawsuits. The multidistrict litigation, with all the federal cases, is positioned for that goal."); Daniel Fisher, Plaintiff Lawyers See Nationwide Settlement As Only End For Opioid Lawsuits, FORBES (Mar. 6, 2018), https://www.forbes.com/sites/legalnewsline/2018/03/06/plaintiff-lawyers-see-nationwide-settlementas-only-end-for-opioid-lawsuits/\#7bc8025c7bc2 [https://perma.cc/62C4-2KGZ].

10. To be clear, there are other potential public health benefits that can flow from public sector litigation and resulting settlement agreements, apart from the recovery of funds. At the same time, it is important not to overstate these benefits. See Derek Carr, Corey S. Davis \& Lainie Rutkow, Reducing Harm Through Litigation Against Opioid Manufacturers? Lessons from the Tobacco Wars, 133 Pub. Health ReP. 207, 210 (2018) (arguing that although there are many potential benefits from public health litigation, "from a public health standpoint, they do not necessarily accomplish more than could be achieved through legislation or regulation and often take far longer").

11. Individual lawsuits were unsuccessful in large part because of the "calculated 'scorched earth' strategy in which tobacco companies made every case prohibitively expensive for even the most determined litigants." D. Douglas Blanke, Towards Health with Justice: Litigation and Public Inquiries and Tools for Tobacco Control, WORLD HEALTH ORG. 8 (2002), https://www.publichealthlawcenter.org/sites/default/files/resources/who-tobacco-litigation-2002.pdf [https://perma.cc/XKP9-WK5C]. One theory underlying the state litigation was that by working together (and relying on outside counsel working on contingency) the states could amass sufficient resources to neutralize the tobacco industry's ability to simply wear down the opposition.

12. Robert L. Rabin, The Tobacco Litigation: A Tentative Assessment, 51 DePAUL L. ReV. 331, 337 (2001). 
responsibility of the cigarette companies, given their history of lying to the public about the addictiveness of nicotine, marketing to youth, suppressing information about the dangers of smoking, and more.

Because the states alleged that they had been directly harmed by the tobacco industry's misconduct, under the states' theory "smokers' conduct, or their knowledge of the health risks, was not a defense ...."13 As Robert Rabin writes, "In reality, these [legal] theories were largely untested, and the claim that the state's interest was independent of and distinct from the individual smoker's generally rested on a shaky foundation."14 But as state after state filed suit, the industry-which had been able to use its superior resources to overpower individual litigantsstarted to feel pressure to settle. ${ }^{15}$ Pressure for a settlement built as the State of Minnesota succeeded in prying loose documents that the tobacco industry had sought to withhold based on misleading or fraudulent claims of attorney-client privilege, further confirming a decades-long pattern of misconduct. ${ }^{16}$

The opioid litigation now being brought by states, localities, and tribal entities is, in some ways, built on a similar legal foundation. ${ }^{17}$ Though they are based on diverse legal doctrines and statutory claims, these lawsuits all similarly rely on the theory that governments are spending billions of dollars to address an opioid epidemic that is, at least in large part, caused by the misconduct of the defendants - and the defendants therefore should be responsible for reimbursing those costs. ${ }^{18}$ As in the tobacco cases, some of the underlying legal theories are untested, ${ }^{19}$ but the

\footnotetext{
13. Blanke, supra note 11, at 25.

14. Rabin, supra note 12, at 337.

15. Id. at 338 ("What the industry was willing to buy, at a very considerable price, was relief
} from litigation uncertainty.").

16. See Michael V. Ciresi, Roberta B. Walburn \& Tara D. Sutton, Decades of Deceit: Document Discovery in the Minnesota Tobacco Litigation, 25 WM. MitChell L. ReV. 477, 478 (1999). The Minnesota litigation ultimately "resulted in the production of approximately thirty-five million pages of internal industry documents." Id. at 479.

17. The details of this litigation will not be reviewed in depth here but are well detailed in another article in this issue. See generally Elizabeth Weeks \& Paula Sanford, Financial Impact of the Opioid Crisis on Local Government: Quantifying Costs for Litigation and Policymaking, 67 U. Kan. L. Rev. 1061 (2019) (discussing how local governments could potentially quantify the impact of the opioid crisis).

18. More specifically, the plaintiffs focus on two primary allegations. "First, the manufacturers overstated the benefits and downplayed the risks of the use of their opioids while aggressively marketing them (the overpromotion claim); and second, that the distributors failed to monitor or detect suspicious orders (the diversion claim)." Nicolas P. Terry, The Opioid Litigation Unicorn, 70 S.C. L. REV. 637, 639 (2019).

19. One main untested issue is whether or not the plaintiffs can rely on aggregate state/municipal costs, or whether they have to identify specific individuals who were harmed by the alleged misconduct. The defendants' discovery requests suggest that they plan to press this issue. See 
steady accumulation of more and more lawsuits raises the stakes and builds pressure for a settlement.

Another important similarity is that both the state tobacco litigation and the current opioid lawsuits are being pursued, on behalf of the plaintiff government entities, by private attorneys who are operating on a contingency fee basis. If there is a large settlement (which some have estimated might be in the range of $\$ 50$ billion $^{20}$ ), these plaintiffs' attorneys stand to gain hundreds of millions of dollars. ${ }^{21}$ In a general sense, this aligns their interests with those of the states and localities they represent, who want to recoup as much money as possible, but it does not give them an incentive to ensure that any resulting proceeds are used for addiction treatment, harm reduction, or to address the root causes of the opioid epidemic. ${ }^{22}$

There are important differences between the two lines of cases as well. For one, the opioid companies' legal defenses may be considerably stronger than the tobacco industry's were. Unlike tobacco, which was virtually unregulated at the federal level at the time of the state lawsuits, "federal laws such as the Food, Drug, and Cosmetic Act regulate nearly every aspect of the prescription drug market, and the Controlled Substances Act subjects certain drugs, including [opioid pain relievers] to even stricter regulation." ${ }^{23}$ Intensive federal regulation may allow for a variety of legal defenses, including claims of federal preemption. The

Hoffman, supra note 9 (“[T]he drug industry is asking for patients' records and for every prescription the plaintiffs deemed medically 'suspicious."”).

20. Andrew Harris, Jared Hopkins \& Hannah Recht, Justice for Opioid Communities Means Massive Payday for Their Lawyers, BLOOMBERG (July 25, 2018), https://www.bloomberg.com/ graphics/2018-opioid-lawsuits/?srnd=prognosis.

21. Id. ("In the fee arrangements reviewed by Bloomberg, the lead lawyers and the dozens of other firms joining them are generally slated to receive anywhere from 25 percent to 33 percent of the total payout, depending on when and how the litigation ends.").

22. There are two other related concerns. One is that outside counsel may push the plaintiffs to accept an early settlement offer instead of holding out for a higher offer. See, e.g., Paul Harzen Beach, The Parens Patriae Settlement Auction, 52 GoNZ. L. REV. 455, 473 (2017) ("'[Outside] counsel has an incentive to settle early, even if that settlement will be inadequate. While a greater settlement will lead to greater total fees for counsel, [they] can maximize their return on investment by settling early."). A second concern is that outside counsel's interest in ensuring they get paid may motivate them to accept a settlement that allows information about the industry's misconduct to stay secret, contrary to the public's interest. See Barry Meier, Opioid Makers Are the Big Winners in Lawsuit Settlements, N.Y. TIMES (Dec. 26, 2018), https://www.nytimes.com/2018/12/26/opinion/opioidslawsuits-purdue-pharma.html [https://perma.cc/YAS6-ZTDD] ("[I]n taking the industry's money quickly, the public will lose its last opportunities to find out about the reckless ways that makers and distributors of opioids acted in pursuit of profit.").

23. Carr, supra note 10. For further discussion of potential legal obstacles (and possible counter-arguments), see Rebecca L. Haffajee \& Michelle M. Mello, Drug Companies' Liability for the Opioid Epidemic, 377 N. ENG. J. MED. 2301 (2017), https://www.nejm.org/doi/10.1056/ NEJMp1710756 [https://perma.cc/QPD2-A2CG]. 
defendants' confidence in their potential legal defenses may help explain why, despite pressure from the judge overseeing the opioid multi-district litigation (MDL), there has been no settlement to date. The weight of the pressure may, of course, change if, as happened in the tobacco litigation, more internal documents emerge detailing the industry's misconduct or collusion.

An additional complication is that, unlike the state suits that led to the MSA, the opioid litigation now involves more than 1500 other municipal jurisdictions - and includes cases in both state and federal court. The decisions of some local governments to file their own suits were a direct response to being left out of the tobacco settlement. For example, the mayor of Missoula, Montana explained his decision to file a lawsuit on behalf of the city by saying, "Tobacco settlement money went to the State of Montana and was not proportionally allocated to communities based on local costs and impact .... We believe that by joining plaintiffs through class action as a municipality, we stand to see direct benefit of settlement." ${ }^{24}$ Needless to say, reaching a settlement with so many more players will be considerably more difficult - and it is not clear that the defendants even have the assets to cover a settlement that will be acceptable to so many different plaintiffs. ${ }^{25}$

Nonetheless, most commentators still believe that a massive settlement of some sort is likely in the opioid litigation (though it may not occur until after "bellwether" trials are concluded). As the opioid cases move in that direction, it is important to review how the settlement proceeds from the MSA were spent and how public health advocates might try to ensure that more of the proceeds from an opioid settlement are committed to alleviating the effects of the current epidemic and preventing the next one.

\section{The MAster Settlement AgreEment}

In November 1998, the major cigarette manufacturers signed the

24. Editorial, Missoula's Fight Against the Opioid Epidemic, Missoulian (Jan. 31, 2019), https://missoulian.com/opinion/editorial/missoula-s-fight-against-the-opioid-epidemic/article_2a45 97c6-227a-595d-86bd-0ebe2f414a55.html [https://perma.cc/8GJF-JL43]. As Elizabeth Weeks has detailed, however, it may be very difficult for local governments to quantify the harms they have suffered as a result of the defendants' misconduct. See generally Weeks, supra note 17.

25. See Terry, supra note 18, at 656-57 ("United States prescription opioid revenue peaked in 2015 at $\$ 8$ billion" while costs attributed to the opioid crisis were estimated to exceed $\$ 500$ billion for that same year). Connecticut Attorney General George Jepson has remarked that " talk of the tobacco settlement raises expectations [for the scope of an opioid settlement] in a way that are probably unfortunate." Demko, supra note 6. 
MSA — still the largest civil litigation settlement in history-in order to settle litigation brought by the attorneys general of forty-six states. ${ }^{26}$ Under the agreement, the cigarette manufacturers agreed to pay the states more than $\$ 206$ billion over twenty-five years. ${ }^{27}$ In return, the states gave up their legal claims against the cigarette manufacturers, including the right to sue the industry for smoking-related costs in the future. Among other provisions, the MSA prohibited targeting of underage persons in tobacco advertising, banned the use of cartoons in cigarette advertising, and sharply restricted brand name sponsorship and outdoor advertising. ${ }^{28}$

At the time, it was clear that one core purpose of the agreement was to provide states with funding for tobacco control programs. ${ }^{29}$ The MSA itself stated that the "the undersigned Settling State officials believe that entry into this Agreement... with the tobacco industry is necessary in order to further the Settling States' policies designed to reduce Youth smoking [and] to promote the public health" and that the agreement would "achieve for the Settling States and their citizens significant funding for the advancement of public health." 30 These statements, however, were in the recitals or "whereas" clauses of the agreement; the operative provisions of the MSA did not contain any binding provisions that required the states to use the funds - or any portion thereof - to fund tobacco prevention and cessation.

Using some (or even a large) portion of the settlement funds for unrelated purposes could be justified under the theory that the lawsuits provided for the recovery of funds that had already been spent on treating tobacco-related illnesses and that, in the absence of the industry's

26. MSA, supra note 2. The four other states-Florida, Minnesota, Mississippi, and Texashad previously reached their own separate settlement agreements that roughly paralleled the MSA. The District of Columbia, American Samoa, Guam, the Northern Mariana Islands, Puerto Rico, and the U.S. Virgin Islands were also signatories to the MSA.

27. MSA, supra note 2, at 28. Though the twenty-five-year mark has been widely used to estimate the scope of the payout, the MSA payments go on in perpetuity, though the amount of future payments is tied to the volume of cigarette sales. The MSA also funded the creation of the American Legacy Foundation, discussed in Part II.D, infra.

28. See id. at 10. Despite these limitations, tobacco industry spending on marketing actually increased following the MSA. Walter J. Jones \& Gerard Silvestri, The Master Settlement Agreement and its Impact on Tobacco Use 10 Years Later, 137 CHEST 692, 695 (2010); Carr, supra note 10. Any global settlement agreement with opioid-related companies is also likely to include conduct restrictions. That part of a potential settlement is not discussed in this article, but the MSA experience highlights to need to design such conduct restrictions carefully.

29. See Campaign for Tobacco-Free Kids, supra note 3; Stephen A. Schroeder, Tobacco Control in the Wake of the 1998 Master Settlement Agreement, 350 N. ENG. J. MED. 293, 295 (2004) ("According to [former Senator John] McCain, at the time of the settlement there was general agreement that the money would be used 'for tobacco education and treatment of smoking-related illnesses."').

30. MSA, supra note 2, at 2. 
misconduct, could have been spent on other purposes. ${ }^{31}$ However, the MSA also barred the states from seeking any cost recovery from the tobacco industry in the future. Thus, if states did not spend some portion of the settlement proceeds on tobacco prevention and cessation, they could continue to incur the same smoking-related costs, without the ability to seek any further legal recourse. So the expressed intention of nearly every attorney general involved in the settlement, at least according to their public statements, was that even if some of the settlement money was spent on other purposes, a significant portion of the funding would be set aside to reduce tobacco use and deal with the attendant public health problems. ${ }^{32}$

But, as stated, this was not a condition of the agreement. And without any requirement that state legislatures use the funds for tobacco-related purposes, for the most part they have not. ${ }^{33}$ In addition to health care, states almost immediately began spending their MSA proceeds to fund education, social services, infrastructure, tax cuts, rainy-day funds, and more. ${ }^{34}$ The latest report by the Campaign for Tobacco-Free Kids found that in 2017, "[S]tates will collect a record $\$ 27.5$ billion in revenue from the tobacco settlement and tobacco taxes[, but] will spend only 2.6 percent of it $-\$ 721.6$ million — on programs to prevent kids from smoking and help smokers quit." 35

Moreover, a number of states have partially or fully securitized their ability to receive future settlement payments. That is, they sold the rights to receive future MSA payments to investors in return for a large lumpsum payment. For example, in 2002, Rhode Island "approved a plan to sell, or securitize, the state's rights to $\$ 1.19$ billion in future tobacco settlement payments, for a smaller, one-time payment of \$600 million."36

31. See General Accounting Office, GAO-01-851, Tobacco Settlement: States' Use of MASter Settlement AgreEMEnt PAyMents 26 (June 2001) ("Because claims for compensation for past health care costs, including Medicaid, were the basis for many of the initial lawsuits filed by the states, many states gave high priority to the use of MSA payments for health related funding and tobacco control programs. Some states also told us that they viewed the settlement payments as an opportunity to fund needs that they were not able to fund previously due to the costs of health care."). At least in the initial years following the MSA, states spent more MSA funds for health care costs than for any other purpose. Id. at 32-34.

32. Campaign for Tobacco-Free Kids, supra note 3.

33. See General ACCOUnTING OFFICE, supra note 31, at 37-41.

34. Id.

35. Campaign for Tobacco-Free Kids et al., Broken Promises to Our Children: A State-by-State Look at the 1998 Tobacco Settlement 19 Years Later 1 (Dec. 13, 2017), https://www.tobaccofreekids.org/assets/content/what_we_do/state_local_issues/settlement/FY2018/ FY2018_state_settlement_report.pdf [https://perma.cc/W27D-RAJC] [hereinafter Broken Promises $2017]$.

36. Campaign for Tobacco-Free Kids et al., Broken Promises to Our Children: A State-by-State Look at the 1998 Tobacco Settlement Thirteen Years Later 79 (Nov. 30, 2011), 
At least 18 and the District of Columbia have at least partially securitized their MSA payments. ${ }^{37}$ In those states, though the industry continues to make its required payments under the MSA, those funds are no longer available to use for tobacco prevention (or any other purpose); instead, when the state receives money from the MSA, it is immediately disbursed to bondholders. ${ }^{38}$

The failure of states to invest — or to consistently invest ${ }^{39}$ —in tobacco control has had immense public health consequences. Although smoking rates have declined substantially since the MSA, "these declines began before the agreement and were likely influenced by contemporaneous tobacco prevention and control efforts." ${ }^{40}$ It is not clear that the MSA changed the trajectory of the decline in smoking rates at all. ${ }^{41}$ Nor has the MSA changed the fact that "[v]ery large disparities in tobacco use remain across racial/ethnic groups and between groups defined by educational level, socioeconomic status, and region." 42 Driving smoking rates down more precipitously and addressing these persistent smoking-related disparities would require "[s]tate capacity and infrastructure, including clear leadership and dedicated resources." 43 The MSA was almost certainly a once-in-a-lifetime opportunity to build such an infrastructure. ${ }^{44}$

The following sub-sections discuss various state-based efforts to try to ensure that MSA proceeds were used for tobacco control, with the experience of Ohio detailed in some depth as a paradigmatic example.

https://www.tobaccofreekids.org/assets/content/what_we_do/state_local_issues/settlement/FY2012/2 011Broken_Promise_Report.pdf [https://perma.cc/S7AR-W24Q] [hereinafter Broken Promises 2011]. For a discussion of a variety of problems associated with MSA-backed bonds, see Cezary Podkul, How Wall Street Tobacco Deals Left States With Billions in Toxic Debt, ProPuBlica (Aug. 7, 2014, 8:00 AM), https://www.propublica.org/article/how-wall-street-tobacco-deals-left-stateswith-billions-in-toxic-debt [https://perma.cc/5S7Z-5N23].

37. Jonathan H. Adler et. al., Baptists, Bootleggers \& Electronic Cigarettes, 33 YALE J. ON REG. 313,354 (2016).

38. Id. at 353-54.

39. States did increase funding for tobacco control in the immediate aftermath of the MSA, but by 2003 , they were spending only $3 \%$ of MSA funds on tobacco control. Jones, supra note 28, at 695 .

40. Carr, supra note 10.

41. Frank Sloan \& Lindsey Chepke, Litigation, Settlement, and the Public Welfare: Lessons from the Master Settlement Agreement, 17 WIDENER L. REV. 159, 184 (2011). The authors also found no evidence that the MSA changed the trajectory of youth smoking rates, except through the MSA's effect on cigarette prices. Id. at 187.

42. U.S. Dept. of Health and Human Services, Public Health Service, Office of the Surgeon General, The Health Consequences of SMoking-50 Years of Progress 17 (2014) https://www.surgeongeneral.gov/library/reports/50-years-of-progress/full-report.pdf [https://perma.cc/ZE9E-6CM2].

43. Id. at 812 .

44. I do not mean to understate the political difficulties that made it difficult to ensure that MSA funds were devoted to tobacco control over the long run — only to note the lost opportunity. 
Though most of these efforts were ultimately unsuccessful, the experience of Florida provides one example of success. The section concludes by discussing the American Legacy Foundation (later renamed the Truth Initiative), which is a national non-profit foundation set up by the MSA to implement tobacco prevention and cessation efforts.

\title{
A. The Ohio Experience ${ }^{45}$
}

Under the MSA, Ohio was scheduled to receive more than $\$ 10$ billion between 2000 and 2026. At the press conference announcing the settlement, then-Ohio Attorney General Betty Montgomery stated, "The reason we got in this fight was to protect public health and prevent underage smoking. A significant portion of this money should go toward these causes." 46 Following the settlement, the governor and the Ohio legislature "created a bipartisan group of Ohio legislators and other public officials ... for the purpose of making recommendations regarding the appropriate use of Ohio's MSA payments." ${ }^{\prime 7}$ The task force

\begin{abstract}
determined that good public policy required that at least a portion of the MSA moneys be permanently and irrevocably committed to the tobacco programs in a manner that would protect them from future efforts to redirect them to other agendas [and it therefore recommended] a sequestered trust fund outside the state treasury, like the state retirement system trusts, to protect it from legislative re-appropriation. ${ }^{48}$
\end{abstract}

The Ohio General Assembly passed the legislation resulting from the task force's recommendations in February 2000. It passed with an overwhelming bipartisan majority in the House (87-9), and by narrower margin in the Senate, where Democrats objected that the plan did not reserve enough of the settlement money for public health purposes. ${ }^{49}$ The legislation created the Tobacco Use Prevention and Control Foundation (the "Foundation"), which was charged with developing and

45. The discussion of Ohio's experience is informed, in part, by the author's personal experiences. From 2005 to 2008, Professor Berman directed the Ohio Tobacco Public Policy Center, which was funded by Ohio's Tobacco Use Prevention and Control Foundation. After Professor Berman left the Center, it closed when Ohio's legislature dismantled the foundation.

46. Campaign for Tobacco-Free Kids, supra note 3, at 5.

47. Amicus Brief of Former Ohio Attorney General Betty D. Montgomery, Former Ohio Senate President Richard H. Finan, and Former Director of the Ohio Department of Health J. Nick Baird, M.D., as Amicus Curiae Supporting Plaintiffs-Appellants at 6, Bd. of Trs. of the Tobacco Use Prevention \& Control Found., et al. v. Boyce, 941 N.E.2d 745 (2010) (No. 10-0118).

48. Id.

49. Andrew Welsh-Huggins, Taft Ready to Approve Tobacco Settlement Spending Plan, ASSOCIATED PRESS (Feb. 17, 2000). 
implementing "a plan to reduce tobacco use by Ohioans, with emphasis on reducing the use of tobacco by youth, minority and regional populations, pregnant women, and others who may be disproportionately affected by the use of tobacco." 50 As recommended by the task force, the law provided that funds appropriated to the Foundation would "not be a part of the state treasury." 51 It also created a schedule of disbursements under which the Foundation would receive $\$ 1.26$ billion through 2012, at which point it would be "self-sustaining" and would run in perpetuity off of its endowment. ${ }^{52}$

In actuality, things did not run according to the task force's (and General Assembly's) plan. The Foundation received the first scheduled payment from the MSA funds of approximately $\$ 330$ million. ${ }^{53}$ But in future years, the subsequent scheduled payments were all diverted into either the state's general fund or to various other programs. In other words, the first payment made by the legislature to the Foundation was also the last. ${ }^{54}$ Each year, when it came time for the General Assembly to pass on a portion of the state's MSA payments to the Foundation, it determined that the Foundation already had enough remaining in its coffers and the money could be better spent elsewhere. ${ }^{55}$

Because of these diverted payments, the Foundation had to make the difficult decision to spend into its principal. Nonetheless, once it got up and running, it carefully followed the Centers for Disease Control and Prevention's (CDC's) recommended best practices for tobacco control programs, and it showed impressive results. ${ }^{56}$ "From 2002 to 2008, Ohio's adult smoking rate declined $24.4 \%$, placing Ohio in the top quartile of states for the steepest declines during that time period." 57 Ohio's high

\footnotetext{
50. Ohio Rev. Code $§ 183.07$ (2000) (repealed 2008).

51. Ohio Rev. Code $\S 183.08$ (2000) (repealed 2008).

52. Ohio Rev. Code $§ 183.02$ (2000) (repealed 2008); Ohio Rev. Code $§ 183.08$ (2000) (repealed 2008). The legislation also provided for smaller payments to seven other trust funds set up to address matters ranging from agricultural support to law enforcement improvements to educational initiatives.

53. This was a combined payment for FY 2001 and FY 2002. Gregory J. Tung \& Stanton A. Glantz, Clean Air Now, But a Hazy Future: Tobacco Industry Political Influence and Tobacco Policy Making in Ohio 1997-2007, UCSF CTR. FOR TOBACCO CONTROL RES. AND ED. 28 (May 2007), https://escholarship.org/uc/item/49n4q7qc [https://perma.cc/47WA-LKNN].

54. This is true with one minor exception. In FY 2005, the Foundation received approximately $\$ 17$ million in funds that had been diverted to other purposes but were unspent and therefore reverted back to the Foundation. Id. at 30 .

55. Id. at 31 .

56. Despite the funding diversions, as of 2006, Ohio was spending more MSA money on tobacco control (nearly \$48 million) than any other state. Jones, supra note 28, at 694.

57. Health Policy Institute OF OHIO, The State of Tobacco Use Prevention and Cessation in Ohio, 7 (June 2015), https://www.healthpolicyohio.org/wp-content/uploads/2016/03/PolicyBrief _Tobacco.pdf [https://perma.cc/YCD2-BAH3].
} 
school smoking rates fell by $38 \%$ over the same period, and middle school smoking rates fell by $47 \% .{ }^{58}$

In 2007, the General Assembly securitized future settlement agreement payments, selling the rights to receive all future MSA payments in return for a large up-front payout. That raised $\$ 5$ billion, which was promptly spent as part of an economic stimulus package, mostly on tax cuts and school construction. ${ }^{59}$ "This action meant that all future MSA payments to Ohio were no longer available for tobacco prevention and control activities." ${ }^{60}$ It also essentially eliminated the possibility that the Foundation would ever be reimbursed for the previous years' payments that had been diverted to other purposes.

The following year, things came to head when, in order to fund another economic stimulus package to jumpstart a still-flagging economy, the governor and the legislative leadership instructed the Foundation to turn over \$230 million of the $\$ 270$ million left in its endowment fund. ${ }^{61}$ Noting that the fund was, by statute "not a part of the state treasury," and thus not subject to the legislature's control, the Foundation refused. ${ }^{62}$ Instead, to protect the money from being diverted away from tobacco control efforts, the Foundation's board quickly transferred \$190 million to the American Legacy Foundation, with the understanding that the funds would be used to support tobacco prevention and cessation efforts in Ohio. ${ }^{63}$

The governor and the General Assembly reacted swiftly, seeking to block the transfer of the $\$ 190$ million by dismantling the Foundation in its entirety. ${ }^{64}$ The legislation to abolish the Foundation passed with overwhelming bipartisan margins in both the House (85-10) and the Senate (29-3). ${ }^{65}$ The legislature made a small appropriation to the Ohio Department of Health, which was put in charge of tobacco control efforts,

58. OHio Tobacco Research and Evaluation Center, OHIO Tobacco Key Indicators REPORT 39 (Sept. 2007).

59. Strickland's Plans, CincinNATI ENQUiRER, Feb. 6, 2008, at B5.

60. HeALTh POLICY InSTITUTE OF OHIO, supra note 57, at 7.

61. Jim Provance, Strickland Loses Fight Over \$200 Million in Tobacco Settlement Money, TOLEDO BLADE (Feb. 10, 2009, 10:36 AM), https://www.toledoblade.com/news/state/2009/ 02/10/Strickland-loses-fight-over-200-million-in-tobacco-settlement-money/stories/200902100012 [https://perma.cc/7MGS-DGHF].

62. Tobacco Use Prevention \& Control Found. Bd. of Trs. v. Boyce, 941 N.E.2d 745, 748 (Ohio 2010) (internal quotations omitted).

63. Id.

64. Id.

65. Abolishment of Tobacco Use Prevention and Control Foundation, 2008 Ohio Laws File 72; Ohio General Assembly Archives, Unofficial Votes for House Bill 544, http://archives.legislature.state.oh.us/votes.cfm?ID=127_HB_544 [https://perma.cc/2WLH-HL7G] (last visited Apr. 3, 2019). 
but virtually overnight, Ohio went from having one of the best-funded tobacco control programs to one of the worst-funded. ${ }^{66}$

In sum, the 2000 Ohio General Assembly made clear, in a bipartisan manner, its intent to establish a long-term plan to adequately fund tobacco control efforts in Ohio and to protect such funds from re-appropriation by future legislatures. But this unmistakable intent-and the structure the General Assembly created - was insufficient to ensure that future General Assemblies would follow through with implementing this plan. Despite the unmistakable success of the Foundation, funds designated for tobacco control were diverted, securitized, and ultimately reclaimed by future legislatures. Only eight years after setting up its plan for allocating MSA payments (with most "no" votes complaining that not enough was being spent on tobacco prevention), the same legislative body voted overwhelmingly to dismantle the Foundation. ${ }^{67}$

\section{B. Other State Examples}

The Ohio experience is emblematic of what happened in a number of other states. Following through on the intent expressed in the MSA, state attorneys general worked with their legislatures to make sure that some portion of the MSA money was set aside for tobacco control. But these attempts to set aside money for public health proved to be short-lived. Ultimately, in nearly every state, the plan to make long-term, sustained investments in tobacco control was not realized and successful tobacco control programs were dismantled - often as the result of budgetary pressures. To briefly summarize a few examples:

North Dakota: Initially, North Dakota only allocated a limited amount of its MSA settlement proceeds to tobacco control. ${ }^{68}$ In 2007, tobacco control advocates gathered signatures to place an initiated statute on the ballot that would dedicate a portion of the MSA funds to tobacco

66. The fight over the Foundation's money went on in the courts for an additional two years. The Ohio Supreme Court ultimately ruled that the contract with the American Legacy Foundation was invalid because the Foundation's board had violated Ohio's open meetings law and that the legislature acted within its authority in abolishing the Foundation. Boyce, 941 N.E.2d at 753.

67. Predictably, Ohio's smoking rate stopped falling - and actually began to rise - after the foundation was eliminated, though changes in CDC survey methodology implemented in 2011 make it difficult to directly compare smoking rates over time. HEALTH POLICY InSTITUTE OF OHIO, supra note 57 , at 2 .

68. Jennifer R. Welle, Jennifer K. Ibrahim \& Stanton A. Glantz, Tobacco Control Policy Making in North Dakota: A Tradition of Activism, UCSF CTR. FOR TOBACCO CONTROL RES. \& EdUC. 4 (June 1, 2004), https://escholarship.org/content/qt9v58x8ps/qt9v58x8ps.pdf [https://perma.cc/XTX4YHBH]. 
prevention and cessation. ${ }^{69}$ In 2008 , the ballot issue passed by a $54 \%-46 \%$ margin, mandating that the state set aside sufficient MSA funds to implement a tobacco control program consistent with CDC best practices. ${ }^{70}$ As a result, North Dakota became one of the few states to fund tobacco control at or near CDC-recommended levels and "[f]rom 2009 to 2015, smoking among North Dakota's high school students fell by 48 percent, from 22.4 percent to 11.7 percent." 71 As in Ohio, however, the success of the program was not sufficient to protect it in the long term. In 2017, when the state faced a budget shortfall, the BreatheND program that had been established as the result of the ballot measure was eliminated, and the budget for tobacco control was cut by nearly $50 \% .^{72}$ Notably, because the 2008 ballot issue had been passed as an initiated statute rather than as a constitutional amendment, the funding system it established could be undone by legislative enactment and this action did not require approval by the voters.

Massachusetts: When the MSA was signed, Massachusetts already had a successful comprehensive tobacco control program in place, funded by the state's cigarette tax. ${ }^{73}$ Following the MSA, the legislature passed a law creating a "Tobacco Settlement Fund" that would receive $50 \%$ of MSA proceeds for three years, and 30\% of MSA proceeds in every year thereafter. ${ }^{74}$ The fund was to be used for "funding health related services and programs including, but not limited to, services and programs intended to control or reduce the use of tobacco." 75

With the influx of MSA funds, the budget for the state's tobacco control program rose to $\$ 54$ million in 2000 - and, as in other states, had the intended effect of sharply reducing adult and youth tobacco use. ${ }^{76}$ But the surge in tobacco control funding was short lived as "the onset of state and national budget crises precipitated severe cutbacks in FY 2002."77

69. See BallotPedia, North Dakota Tobacco Use Prevention and Control Program Initiative, Measure 3 (2008), https://ballotpedia.org/North_Dakota_Tobacco_Use_Prevention_and_Control_ Program_Initiative,_Measure_3_(2008) [https://perma.cc/6HG4-URD2] (last viewed Apr. 3, 2019).

70. Id.

71. Broken Promises 2017, supra note 35, at 7.

72. Id.; Kaley Schwab, BreatheND Closes as Department of Health Takes Over Tobacco Prevention, KXNET.COM, (June 16, 2017, 6:02 PM), https://www.kxnet.com/news/bismarcknews/breathend-closes-as-department-of-health-takes-over-tobacco-prevention/743696054 [https://perma.cc/2FJQ-8SCZ].

73. Howard K. Koh, et al., The First Decade of the Massachusetts Tobacco Control Program, 120 Pub. HEalth ReP. 482, 490 (2005).

74. MASS. GEN. LAWS ch. 29, § 2XX (2001) (repealed 2003).

75. Id. at (b).

76. Koh, supra note 73 , at 491.

77. Id. 
Governor Jane Swift used emergency powers to unilaterally cut the tobacco control program's budget by $\$ 22$ million. This decision was challenged in court by the American Cancer Society, which argued that the governor's emergency powers did not extend to the Tobacco Settlement Fund because the fund's use had been restricted to a specific purpose by the legislature. ${ }^{78}$ The state's highest court, the Massachusetts Supreme Judicial Court, ultimately ruled in favor of the governor, and "[t]his decision opened the door for a series of further cuts, ultimately leading to the nearly complete defunding of the [Massachusetts Tobacco Control Program]." ${ }^{, 79}$

Mississippi: Mississippi was one of the four states that concluded its own settlement agreement with the cigarette companies prior to the MSA. Under that agreement, in addition to the annual payments made directly to the State of Mississippi, the cigarette companies were to pay $\$ 61.8$ million directly to a pilot program "aimed specifically at the reduction of the use of Tobacco Products by children under the age of 18 years." 80 The Partnership for a Heathy Mississippi ("Partnership") was set up as a private, non-profit entity to receive this $\$ 61.8$ payment and operate the pilot program. ${ }^{81}$ With this funding, the Partnership implemented a highly successful youth prevention program. Between 1999 and 2001, the number of public middle school students reporting current tobacco use fell by $26.7 \%$, and the high school smoking rate also fell by about a third. ${ }^{82}$

In 2000, at the request of the state's attorney general, the court overseeing the settlement agreement ordered that \$20 million of the settlement payments should be directed to the Partnership each year, rather than to the state, to continue its tobacco prevention work. ${ }^{83}$ The state (led by Governor and former Philip Morris lobbyist Haley Barbour) intervened, asserting that the Attorney General could not unilaterally modify the settlement agreement and that the state was entitled to receive the full amount of the annual payments. ${ }^{84}$ In 2007, the Mississippi

78. Brief of Plaintiff-Appellants, New England Div. of the Am. Cancer Soc'y v. Sullivan, 769 N.E.2d 1248 (Mass. 2002) (No. SJC-08765), 2002 WL 33773710, at 28.

79. Koh, supra note 73 , at 491.

80. Hood ex rel. State Tobacco Litig. v. State, 958 So. 2d 790, 795 (Miss. 2007).

81. Id.

82. Michael S. Givel \& Stanton A. Glantz, Political Reform and Tobacco Control Policy Making in Mississippi From 1990 to 2001, UCSF CTR. FOR TOBACCO CONTROL RES. AND ED. 4 (Mar. 1, 2002), https://escholarship.org/uc/item/12x7g2h9 [https://perma.cc/3DXL-8YTY]; Emily McClelland, Nell Valentine \& Robert McMillen, Tobacco Use Trends among Mississippi Youth Following the 1997 Settlement of Mississippi's Medicaid Lawsuit and Subsequent Tobacco Prevention Initiatives, 56 J. Miss. ST. MED. Ass'N 328, 330 (2015).

83. See Hood, 958 So. 2d at 792-93.

84. Id. at 793 . 
Supreme Court ruled that there had been no properly executed modification to the settlement agreement and therefore the ongoing payments to the Partnership were improper. In addition to halting future payments, it ordered the Partnership to return to the state all payments it had received since $2000 .{ }^{85}$ Though the state continued to support some tobacco prevention programming operated through the Department of Health, spending fell off precipitously. ${ }^{86}$ Mississippi now spends less than $25 \%$ of the CDC-recommended amount on tobacco control programming (\$8.4 million in FY2018). ${ }^{87}$

Mississippi provides an interesting case study in "what might have been." The creation of a private foundation (wholly outside state government) that was the direct recipient of settlement proceeds was a promising model, and proved to be successful in the short term. But because the settlement agreement only funded the Partnership for two years, with future payments dependent on the state legislature, its programming was not sustained. Whether a longer-term plan to fund the Partnership would have survived the inevitable legal and political attacks is unknown.

Other States: Similar stories could be told about numerous other states, including Washington, ${ }^{88}$ Indiana, ${ }^{89}$ Illinois, ${ }^{90}$ Hawaii, ${ }^{91}$ and Minnesota. $^{92}$ Among those states that initially invested a significant

85. Id. at $815-16$.

86. Broken Promises 2017, supra note 35.

87. Id.

88. Id. at 8 ("Washington state, which had a well-funded prevention program before funding was virtually eliminated in FY2012, reduced adult smoking by one-third and youth smoking by half from the initiation of its program in 1999 to 2010.").

89. Stephen J. Jay, Mohammad R. Torabi \& Miranda H. Spitznagle, A Decade of Sustaining Best Practices for Tobacco Control: Indiana's Story, 9 PREventing Chronic Disease E3 (2002) (detailing how the independent state agency created in the wake of the MSA operated from 2000 until 2011 and was then dismantled by the legislature).

90. Randy Uang, Richard Barnes \& Stanton A. Glantz, Tobacco Policymaking in Illinois, 19652014: Gaining Ground in a Short Time, UCSF CTR. FOR TOBACCO CONTROL RES. AND EDU. 282 (May 1, 2014), https://escholarship.org/uc/item/6805h95r [https://perma.cc/T5YZ-DDA7] ("The state tobacco control budget underwent a period of high appropriations in the early 2000 s only to fall precipitously and remained at a lower level throughout the mid- and late 2000s and early 2010s.").

91. Richard L. Barnes, Jennifer R. McCarthy \& Stanton A. Glantz, Tobacco Control in Hawai ' $i$ : Progress in Paradise, UCSF CTR. FOR TOBACCO CONTROL RES. \& EDU. 4 (July 14, 2008), https://escholarship.org/uc/item/6696s2c8 [https://perma.cc/88ET-WGRQ] ("Heavy lobbying by the University of Hawai'i to raid the MSA funds to build medical school facilities robbed tobacco control programs of vital resources. The $25 \%$ of the MSA funds that goes to the Department of Health is to be spent for a variety of health promotion and disease prevention programs, but the Department allocates relatively little to tobacco control.").

92. David F. Sly et al., The Outcome Consequences of Defunding the Minnesota Youth TobaccoUse Prevention Program, 41 PREventative MED. 503, 504 (2005) (describing how Minnesota's youth-focused public education campaign was launched with MSA funds in 2000 but eliminated by 
portion of MSA proceeds (and many did not even do that), those investments were not sustained over the long term. Despite strong evidence that these programs were successfully reducing tobacco usewhich, over time, saves states money ${ }^{93}$ - the urge to redirect the MSA funds proved irresistible to governors and state legislatures, especially when the states' economies inevitably hit hard times. In-fighting among health-related groups also contributed to the declines in funding. In several cases, tobacco prevention funds were diverted to other healthrelated purposes, such as building new cancer centers, ${ }^{94}$ reflecting the long-standing difficulty in adequately funding public health and prevention when medical care provides much more immediate and tangible results (and political payoff) ${ }^{95}$ The behind-the-scenes role of the tobacco industry in discouraging investments in tobacco control was also a factor in at least some cases. ${ }^{96}$

Importantly, the structural mechanism used to try to ensure that tobacco control funds would be sustainable did not appear to matter. Setting up a foundation with funds that were "not a part of the state treasury" $" 97$ did not provide adequate protection, since a foundation that had been created by the legislature could also be dismantled later on by the same legislature. Legal challenges pointing out that MSA funds had already been dedicated to a particular purpose were unsuccessful; what one legislature and governor had committed to, a later governor and

the legislature in 2003).

93. Julia A. Dilley et al., Program, Policy, and Price Interventions for Tobacco Control: Quantifying the Return on Investment of a State Tobacco Control Program, 102 AM. J. PuB. HeALTH e22, e27 (2012) (finding that over 10 years, the return on investment for Washington State's tobacco program was more than $\$ 5$ for each $\$ 1$ spent); James Lightwood \& Stanton A. Glantz, The Effect of the California Tobacco Control Program on Smoking Prevalence, Cigarette Consumption, and Healthcare Costs: 1989-2008, 8 PLOS ONE 1 (2013) ("Between FY 1989 and 2008 the California Tobacco Program cost $\$ 2.4$ billion and led to cumulative NIPA healthcare expenditure savings of $\$ 134$ (SE \$30.5) billion.”).

94. See, e.g., Barnes, supra note 91, at 4.

95. J. Michael McGinnis, Pamela Williams-Russo \& James R. Knickman, The Case for More Active Policy Attention to Health Promotion, 21 Health AfF. 78, 78 (2002) (“Approximately 95 percent of the trillion dollars we spend as a nation on health goes to direct medical care services, while just 5 percent is allocated to population wide approaches to health improvement. However, some 40 percent of deaths are caused by behavior patterns that could be modified by preventive interventions."). In the tobacco context specifically, underfunding may partially be due to longstanding stigma against smokers, who are blamed for their own addiction.

96. See, e.g., Jones, supra note 28, at 696 (discussing the example of Texas). Though this may be less of an issue in the opioid context, it is certainly possible that pharmaceutical companies would push states to spend settlement money in the health care sector, rather than on public health and prevention.

97. Tobacco Use Prevention \& Control Found. Bd. of Trs. v. Boyce, 941 N.E.2d 745, 748 (Ohio 2010) (internal quotations omitted). 
legislature (or, in the case of Massachusetts, just the governor) could undo. Even in the case of North Dakota, where the state's citizens voted by a clear margin to dedicate funds to tobacco control, the legislature was willing to dismantle the state's successful program less than a decade later.

\section{The Florida Exception}

There is, however, one exception to the rule that all state efforts to set aside a significant portion of settlement funds for tobacco control have failed. That exception is the case of Florida, where a voter-initiated constitutional amendment has, since 2006, provided significant funding for the state's youth tobacco prevention program. ${ }^{98}$

Florida's story started out like that of most other states. A substantial portion of settlement funds was used for tobacco control in 1998 and 1999, and the program quickly demonstrated success in reducing youth smoking rates. 99 "Smoking prevalence among middle school students dropped by $40 \%$ and among high school students by $18 \%$ during the program's first 2 years." 100 Starting in 1999, however, the legislature and governor made deeper and deeper cuts to the program. By "fiscal year 2004, the program was essentially eliminated, with a budget slashed to $\$ 1$ million." 101 Predictably, as the state cut funds for the program, the decline in youth smoking rates slowed considerably. ${ }^{102}$

98. Florida was one of the four states that settled with the tobacco industry prior to the MSA. That difference is immaterial to the issue of the allocation of settlement funds discussed here. Shortly after the MSA, four other states (Louisiana, Montana, Oklahoma, and Utah) passed legislativelyinitiated constitutional amendments to govern the use of some or all MSA proceeds. GENERAL ACCOUNTING OFFICE, supra note 31, at 21. Unlike the Florida case, though, these were not designed to fully fund an effective tobacco control program. Of these, the Oklahoma constitutional amendment has been most successful in ensuring that at least some MSA funds are used to support tobacco control programs. See Andrew Spivak \& Michael S. Givel, From Industry Dominance to Legislative Progress: The Political and Public Health Struggle of Tobacco Control in Oklahoma, U. OF OKLA. DEP'T OF POL. SCI. 8 (July 1, 2005), https://cloudfront.escholarship.org/dist/prd/content/ qt65d3s7qb/qt65d3s7qb.pdf [https://perma.cc/JAX4-KDZA] (explaining that voters approved the creation of a "constitutionally protected Tobacco Settlement Endowment Trust Fund" in 2000, "but funding for tobacco control programs from the trust fund has been slow due to the requirement to spend only the interest and dividends and not the [principal]").

99. Michael S. Givel \& Stanton A. Glantz, Failure to Defend a Successful State Tobacco Control Program: Policy Lessons from Florida, 90 AM. J. PUB. HeAlTh 762, 762 (2000).

100. Allison Kennedy et al., Strong Tobacco Control Program Requirements and Secure Funding Are Not Enough: Lessons from Florida, 102 AM. J. PUB. HEALTH 807, 807 (2012).

101. Id.

102. FlA. DEP'T OF HEALTh, Florida Youth Tobacco Survey (FYTS), http://www.floridahealth.gov/statistics-and-data/survey-data/florida-youth-survey/florida-youthtobacco-survey/index.html [https://perma.cc/ZLA6-FHMN] (last modified Feb. 8, 2019, 2:35 PM). For a visual representation of this data, see Tobacco Free Partnership of Levy County, Teen Smoking Rates at All-Time Low (Sept. 23, 2015), http://www.tfp-levy.org/news_archives/20150923_news.html 
But unlike in other states, public health groups tried a new strategy in response. In 2006, the American Cancer Society, the American Lung Association, the American Heart Association, and the Campaign for Tobacco-Free Kids collectively spent more than $\$ 5$ million to place a constitutional amendment on the statewide ballot. ${ }^{103}$ The amendment required the state to allocate approximately $\$ 57$ million (" $15 \%$ of 2005 Tobacco Settlement payments to Florida"), adjusted annually for inflation, "for a comprehensive statewide tobacco education and prevention program using Centers for Disease Control best practices."104 The amendment passed with more than $60 \%$ of the vote. ${ }^{105}$

Since 2007, the Tobacco-Free Florida program (which is part of the state's health department) has been funded through this constitutional amendment, and the results have been impressive. Florida now boasts one of the lowest youth smoking rates in the country, at 3.6\%, less than half the national average of $8.1 \% .{ }^{106}$ The adult smoking rate has declined as well, though not as precipitously. ${ }^{107}$ Tobacco-Free Florida claims that since 2007, "[t]here are now approximately 451,000 fewer adult smokers in Florida . . . and the state has saved $\$ 17.7$ billion in health care costs." 108

Florida's success has not been unqualified. Strong funding for a tobacco control program is no guarantee of high quality and effective leadership, and tobacco control advocates have, at times, criticized

[https://perma.cc/YSH5-N8QL].

103. Kennedy, supra note 100 , at 807 .

104. BallotPedia, Florida Amendment 4, Use of Tobacco Settlement Funds (2006), https://ballotpedia.org/Florida_Amendment_4,_Use_of_Tobacco_Settlement_Funds_(2006) [https://perma.cc/AYB3-B2NQ] (last visited Apr. 3, 2019).

105. Id. Interestingly, there does not appear to have been any organized opposition to this ballot measure.

106. Campaign for Tobacco-Free Kids, Key State Specific Tobacco-Related Data \& Rankings 1 (Mar. 19, 2019), https://www.tobaccofreekids.org/assets/factsheets/0176.pdf [https://perma.cc/ LWN3-7MH8]. Comparisons between states are not precise, because of different surveys used to calculate youth smoking rates. Similarly, it is difficult to compare reductions in rates over time because of different surveys and methodologies used, but it appears likely that since 2007 youth smoking rates have declined more rapidly in Florida than in most other states. For instance, the Florida Youth Tobacco Survey reported a 71\% decline in high school smoking from 2007 to 2017 (14.5\% to $4.2 \%$ ), while the Youth Risk Behavior Surveillance System (YRBSS) reported a national decline of $56 \%(20 \%$ to $8.8 \%)$ over that same period. Id.

107. Christine Sexton, Tobacco Funding Fight Extinguished In Florida CRC, NEwSDAYTONABEACH.com (Mar. 23, 2018), http://www.newsdaytonabeach.com/news-service-offlorida/tobacco-funding-fight-extinguished-in-florida-constitution-revision-commission/ [https://perma.cc/9DQG-8MYQ] ("According to the Florida Department of Health ... [i]n 2006, the adult smoking rate was 21 percent, and in 2015 it was 15.8 percent, the lowest it has ever been.").

108. Bureau of Tobacco Free Florida, Bureau of Tobacco Free Florida's Statement Regarding Youth Electronic Cigarette Use (Dec. 20, 2018), http://tobaccofreeflorida.com/wpcontent/uploads/2018/12/Bureau-of-Tobacco-Free-Florida-Statement-Regarding-Youth-ElectronicCigarette-Use.pdf [https://perma.cc/893C-3RBP]. 
Florida's program for devoting funds to "low-impact tobacco control strategies."109 Additionally, even though the amendment guarantees funding for tobacco control programming, the legislature has nonetheless tried to divert a significant amount of the funding to biomedical research and medical schools. ${ }^{110}$ These efforts have, for the most part, been defeated, but protecting the tobacco control programs requires constant vigilance from public health groups. ${ }^{111}$

Though the governor and the legislature still have the ability to influence Tobacco-Free Florida's direction, they are bound by the amendment to provide it with adequate funding to run an effective tobacco control program. ${ }^{112}$ And Tobacco-Free Florida is, in turn, required by the Amendment to follow CDC's best practices. And because these requirements are now written into the state constitution, overturning them would require a vote of more than $60 \%$ of the electorate. ${ }^{113}$ This has proven to be the most stable way of adequately funding a tobacco control program.

Florida is the only example of a state using a constitutional amendment to ensure that settlement proceeds are spent on tobacco control, but several other states have pursued constitutional amendments to increase tobacco taxes and devote a portion of the proceeds to reducing tobacco use. ${ }^{114}$ These efforts have failed more often than they have succeeded, but the potential of this approach was demonstrated in 2016, when California voters approved a constitutional amendment increasing the state's tobacco tax by $\$ 2$ per pack and devoting $13 \%$ of the resulting revenue (estimated at more than $\$ 200$ million per year) to tobacco prevention and cessation. ${ }^{115}$ As with the MSA proceeds, constitutional amendments provide the best hope for ensuring that tax revenues are directed to tobacco control efforts; where tax revenue has been dedicated to public health through initiated statutes, such funding has proven to be

\footnotetext{
109. Kennedy, supra note 100, at 807.

110. Allison Kennedy et al., Tobacco Control in Florida 1999-2011: The Good, The Bad, and the Ugly, UCSF CTR. FOR TOBACCO CONTROL ReS. \& EDUC. 236 (Sept. 2011).

111. Indeed, in 2018, the Florida Constitution Revision Commission (which meets once every 20 years) discussed proposing a ballot issue to undue the amendment's requirement. Due to strong opposition from public health groups, the issue was not referred to the ballot. Sexton, supra note 107.

112. Importantly, that amount of funding is adjusted for inflation, so it remains sufficient for the program's needs over time.

113. Kennedy, supra note 100, at 101.

114. K.L. Lum, R.L. Barnes \& S.A. Glantz, Enacting Tobacco Taxes by Direct Popular Vote in the United States: Lessons from 20 Years of Experience, 18 TOBACCO CONTROL 377, 378 (2009) (noting failed constitutional amendments in Missouri and Oregon, but a successful one in Colorado).

115. Broken Promises 2017, supra note 35, at 1.
} 
unsustainable. ${ }^{116}$

\section{American Legacy Foundation/Truth Initiative}

As previously mentioned, not all of the MSA proceeds went to the states. The agreement also provided for the establishment of a foundation to support "the study of and programs to reduce Youth Tobacco Product usage and ... to prevent diseases associated with the use of Tobacco Products in the States." 117 Cigarette manufacturers were required to make payments totaling $\$ 1.7$ billion to the foundation between 1995 and 2008. ${ }^{118}$ These provisions resulted in the creation of the American Legacy Foundation, renamed the Truth Initiative in 2015. Though the Truth Initiative no longer receives payments through the MSA, it has pursued a fiscal strategy to extend its life and impact. As of 2018, it held more than $\$ 800$ million in investments. ${ }^{119}$

The Truth Initiative is engaged in four primary activities:

(i) youth/young adult public education (primarily through the truth $\mathbb{R}$ anti-tobacco counter-marketing campaign), (ii) research policy and practice including... [the] Schroeder Institute for Tobacco Research and Policy Studies[,] (iii) community and youth engagement activities ... and (iv) using innovative digital tools to design, build and market effective and scalable approaches to smoking cessation. ${ }^{120}$

The Truth Initiative's signature program is the award-winning truth $\AA$ counter-marketing campaign, which "features fast-paced, hard-edged ads that present facts about the addictiveness of smoking, the number of deaths and amount of disease attributed to smoking, the ingredients in cigarettes, and the marketing practices of the tobacco industry."121

116. See, e.g., Michael Siegel, The Effectiveness of State-Level Tobacco Control Interventions: A Review of Program Implementation and Behavioral Outcomes, 23 ANN. REV. PuB. HEALTH 45, 47 49 (2002) (discussing diversion of tobacco tax funds allocated by ballot initiative in California and Massachusetts).

117. MSA, supra note 2, at 41 .

118. MSA, supra note 2, at 42 . The payment amounts are subject to some adjustments based on inflation and the volume of tobacco sales. Id. at $42-43$.

119. Truth Initiative, Truth Initiative Foundation and Affiliate: Consolidated Financial Report 3 (June 30, 2018).

120. Id. at 7 .

121. Jane A. Allen, et al., The truth ${ }^{\circledR}$ Campaign: Using Countermarketing to Reduce Youth Smoking, in The New World of Health Promotion: New Program Development, IMPLEMENTATION AND EVALUATION 196 (Bernard J. Healey \& Robert S. Zimmerman, Jr., eds) (2010). Importantly, the truth ${ }^{\circledR}$ campaign has eschewed the discredited "just say no" approach to public health campaigns and has instead pioneered new methods that have been effective in influencing youth opinions and changing social norms surrounding smoking. Id. 
The Truth Initiative - and the truth ${ }^{\circledR}$ counter-marketing campaign, in particular - have arguably been the most significant and impactful element of the MSA. A 2005 study found that between 1999 and 2002, "smoking prevalence among [middle- and high-school] students declined from $25.3 \%$ to $18.0 \% \ldots$ and that the [truth $\left.{ }^{\circledR}\right]$ campaign accounted for approximately $22 \%$ of this decline." 122 A more recent study estimated that in the course of just one year, the truth ${ }^{\circledR}$ campaign prevented more than 300,000 youth and young adults from smoking. ${ }^{123}$ In short, the $\$ 1.7$ billion committed to the American Legacy Foundation/Truth Initiative has had a tremendous return on investment in terms of reducing youth smoking ${ }^{124}$ perhaps as much or more than the over $\$ 150$ billion that has already been paid to the states.

As with any effective tobacco control program, the truth ${ }^{\circledR}$ campaign has come under attack and has required defending. Most notably, Lorillard Tobacco Company sued the foundation in 2002, alleging that its hardhitting truth ${ }^{\circledR}$ advertisements violated the MSA's "vilification clause," which prohibits "any personal attack on, or vilification of" a tobacco company or executive. ${ }^{125}$ In 2006, the Delaware Supreme Court ruled in favor of the American Legacy Foundation, ${ }^{126}$ but the extensive legal battle "significantly burdened the Foundation, consuming financial and human resource that could have been otherwise spent on the public health mission of the organization."127 Despite this and other challenges, ${ }^{128}$ directing settlement proceeds to a national non-profit foundation that is not beholden to (or subject to the changing preferences) any of state legislature has been the most secure way of ensuring that settlement funds are spent

122. Matthew C. Farrelly, et al., Evidence of a Dose-Response Relationship Between "truth" Antismoking Ads and Youth Smoking Prevalence, 95 AM. J. PUB. HeAlth 425, 425 (2005). This evaluation included authors from the American Legacy Foundation, and so was not fully independent.

123. Donna Vallone et al., The Effect of Branding to Promote Healthy Behavior: Reducing Tobacco Use among Youth and Young Adults, 14 InT'L. J. EnV. Res. \& PUB. Health 1517, 1517 (2017). Again, authors include Truth Initiative researchers.

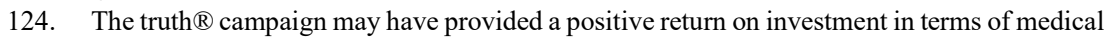
costs averted as well. See David R. Holtgrave et al., Cost-Utility Analysis of the National truth ${ }^{\circledR}$ Campaign to Prevent Youth Smoking, 36 AM. J. Preventive Med. 385, 385, 387 (2009) (estimating that the 2000-2002 truth ${ }^{\circledR}$ campaign averted $\$ 1.9$ billion in medical costs for society, while costing \$324 million).

125. MSA, supra note 2, at 47. For a detailed review of this litigation, see J.K. Ibrahim \& Stanton A. Glantz, Tobacco Industry Litigation Strategies to Oppose Tobacco Control Media Campaigns, 15 TOBACCO CONTROL 50 (2006). Technically, the American Legacy Foundation was the plaintiff in the suit, because in the face of repeated legal threats from Lorillard, it filed for a declaratory judgement that it was not in violation of the MSA.

126. Lorillard Tobacco Co. v. Am. Legacy Found., 903 A.2d 728, 732 (Del. 2006).

127. Allen, supra note 121, at 205.

128. For further discussion of the challenges the foundation has faced, see Cheryl G. Healton, M. Lyndon Haviland \& Ellen Vargyas, Will the Master Settlement Agreement Achieve a Lasting Legacy?, 5 HEALTH PROMOTION PRAC. 12S (2004). 
on their intended purpose.

\section{LESSONS LEARNED FOR POTENTIAL OPIOID SETTLEMENTS}

Keeping in mind that the opioid litigation differs in significant ways from the tobacco litigation, what are the lessons from the use of MSA proceeds that could inform efforts to ensure that a substantial portion of future opioid settlement agreement funds are used to advance public health? This can be broken down into two different questions: (1) could a future settlement directly, through its terms, ensure that settlement proceeds are used for public health purposes?, and, if not, (2) what can be done at the state or local level to ensure that settlement funds are applied to their intended purpose? The experience of the MSA does not fully answer either one of these questions, but it provides some potential guidance.

\section{A. Direct Allocation for Public Health}

The experience of the MSA money being diverted away from use for tobacco prevention and cessation raises an obvious question: what if the MSA had mandated that the funds be used in a particular way, rather than merely placing aspirational language in the "whereas" clauses? When asked about this, Joe Rice of Motley Rice LLC, who was lead counsel for about half of the states in the tobacco litigation-and is now co-lead counsel for the plaintiffs in the opioid MDL—said, "There was a wide range of views among the AGs [attorneys general] about how far they could go to specifically allocate funds for specific uses .... [Although some were supportive,] others felt it was a legislative function to appropriate all the money and did not support directing the funds." ${ }^{129} \mathrm{He}$ added that "[i]f we'd gone much further [in mandating that funds be used for tobacco control], we could have had a separation of powers disagreement and may have needed legislative approval of the settlement." 130 In other words, at least some of the attorneys general either did not think they had the legal authority to direct settlement funds to specific purposes, ${ }^{131}$ or did not think it was their appropriate role to do

129. Allison Torres Burtka, '98 Settlement Agreement, AM. Museum of TORT L., https://www.tortmuseum.org/98-tobacco-settlement/ [https://perma.cc/HG33-X66P] (last visited Apr. 3, 2019).

130. Id.

131. Then-Connecticut Attorney General (and now U.S. Senator) Richard Blumenthal says that at the time "“[t]he conclusion was that it would be unconstitutional," but he now wishes that this conclusion had been tested in court. Demko, supra note 6. 
so. ${ }^{132}$

Though an attorney general could not instruct a state legislature to spend state funds in a particular way, is it possible that a state's attorney general could sign a settlement agreement directly allocating proceeds to a non-governmental entity - thereby evading legislative appropriation altogether? Whether or not this would violate a state's separation of powers doctrine would be a question of state constitutional law, and states may differ on the answer. But somewhat surprisingly, there do not seem to be any cases squarely addressing this question. ${ }^{133}$ The closest example in the tobacco context is the example of Mississippi, discussed above, where the settlement agreement (which was separate from the MSA) called for a $\$ 61.8$ million payment to be made directly to a private, nonprofit entity, the Partnership for a Healthy Mississippi, to support youth tobacco prevention programming. This original allocation was not challenged - the later Hood litigation only involved subsequent payments made to the Foundation after the attorney general had purported to modify the settlement agreement. In that litigation, the governor and legislature raised a separation of powers challenge to the payments, but the court did not reach that issue because it found that the settlement agreement had not been properly modified, and therefore the later payments were not authorized.

One potential way to avoid (or at least mitigate) the separation of powers issue would be for a settlement to provide that in order for a state to receive settlement funds, it must pass legislation directing a set portion of the settlement funds to a non-profit foundation in its state that would use those funds for opioid-related prevention, treatment, and education. In this way the state legislature would be directly authorizing the payment (though under some pressure), which would make a separation of powers challenge more difficult. A somewhat similar mechanism was used in the MSA. In order for states to receive the full amount of their promised payments under the MSA, they were required to pass legislation ensuring

132. Alternatively, it may have been that they were yielding to political pressure. Former Maine Attorney General James Tierney recalls, "There was a lot of pressure from governors and legislators.... They really wanted the money." Id. In later testimony before the U.S. Senate, a representative of the National Governors Association argued that "given the long history of state expenditures for smoking-related illnesses and the fiscal pressures facing the states, the financial flexibility provided to the states in the MSA is not only appropriate, but vitally necessary." State Spending of Tobacco Settlement Revenues: Hearing Before the S. Comm. on Com., Sci., and Transp., 108th Cong. 25 (2003) (statement of Raymond C. Scheppach).

133. Even if one agrees with how such power is used in any given case, there could of course be policy objections to attorneys general having such broad authority to direct the spending of funds that are, in essence, being paid to the state. 
that tobacco companies who were not parties to the agreement would be required to make "escrow" payments to the states that roughly paralleled the payments made by the defendants. ${ }^{134}$ This MSA provision has been criticized as unduly "collusive and coercive," because it essentially forced state legislatures to protect the tobacco companies' economic interests. ${ }^{135}$ But the MSA's approach has withstood numerous legal challenges, ${ }^{136}$ and it is arguably far more appropriate to use such a mechanism to ensure that some portion of settlement funds are set aside for their intended purpose.

Whatever the mechanism, trying to follow and expand upon the Mississippi model and send settlement payments directly to nongovernmental, state-based foundations would, of course, be complicated, particularly in the context of a national settlement. ${ }^{137}$ But the legal and practical viability of such an approach deserves further scrutiny. Such an approach could be a viable way of resolving the likely challenge that settlement proceeds will be inadequate to meet all of the 1500-plus plaintiffs' needs and expectations. Allocating proceeds to fifty state-based entities seems far more feasible than dividing funding among more than 1500 localities, and state-based foundations (similar to the Partnership for a Healthy Mississippi) model could then act as grant-making entities responsible for making the difficult decisions about how to prioritize and allocate spending within the state. Most critically, ensuring that some portion of the funds are never subject to legislative appropriation provides the best chance of ensuring that the money is not diverted (either immediately or later on) to other purposes.

Along those lines, there do not seem to be any obvious legal barriers to following the MSA's model and allocating a share of any resulting settlement to a national foundation like American Legacy

134. MSA, supra note 2, at 58-68. For more detail on this provision, see generally Andrew J. Haile \& Matthew W. Krueger-Andes, Landmark Settlements and Unintended Consequences, 44 U. TOL. L. REV. 145 (2012)

135. Thomas C. O'Brien, Constitutional and Antitrust Violations of the Multistate Tobacco Settlement 3 (May 18, 2000), https://object.cato.org/pubs/pas/pa371.pdf [https://perma.ce/FW7F3RCV]. See also Haile, supra note 134, at 175 ("Whether or not this [MSA provision] constitutes a violation of the separation of powers requirement, it certainly amounts to an unprecedented abrogation of legislative power by the state and blurs the lines between the legislative and executive branches.").

136. See Bruce Yandle et. al., Bootleggers, Baptists \& Televangelists: Regulating Tobacco by Litigation, 2008 U. ILL. L. REV. 1225, 1276-77 (2008).

137. How protected such a foundation would be from political interference would also depend upon its structure and the specifics of state law. See J.K. Ibrahim, T.H. Tsoukalas \& S.A. Glantz, Public Health Foundations and the Tobacco Industry: Lessons from Minnesota, 13 TOBACCO CONTROL 228, 228 (2004) (discussing how the Minnesota Partnership for Action Against Tobacco, which was set up as a private foundation to spend MSA funds, was "insulat[ed] from traditional political attacks through the legislative process or executive branch, but left it vulnerable to attacks by the attorney general, who has responsibility for oversight of private foundations in most states"). 
Foundation/Truth Initiative. Given the Truth Initiative's record of accomplishment - in contrast to the states' diversion of settlement funds away from their intended purpose - a strong case could be made for allocating a significant share of any settlement to such a foundation. Indeed, Mike Moore has stated that he regrets the widescale diversion of tobacco settlement funds, and that "[t]his time, he wants a comprehensive, company-funded national program that would make treatment more widely available . . . as well as expand prevention education." ${ }^{138}$ There are obvious political barriers to allocating money to a national foundation, rather than to the plaintiffs, ${ }^{139}$ but there may not be a more effective way of spending money to promote public health. Requiring that some percentage of the foundation's money is redirected to state-based or local prevention and treatment programs (again, perhaps, through a grantmaking process) could help reduce the sting of reducing the amount of settlement revenue paid directly to the plaintiff governmental entities. ${ }^{140}$

\section{B. Ensuring that State Settlement Proceeds are Spent on Public Health}

Assuming that settlement proceeds are sent directly to the plaintiffs, what can be done to ensure that legislatures or city councils spend the money (or a portion of it) to benefit public health? The main lesson of the state experiences with tobacco settlement proceeds is clear: good intentions and even statutory promises to spend settlement dollars on public health are not sufficient. When hard fiscal times inevitably arise, the pressures to reallocate the funds to short-term needs, or even to sacrifice future settlement payments for an immediate payout, prove too strong to resist. This proved to be the case even where, as in Ohio, the legislature set up an endowed foundation to administer its tobacco control program, ${ }^{141}$ and in cases like North Dakota, where the voters expressly indicated their desire to adequately fund tobacco prevention efforts. Because a current legislature cannot make commitments on behalf of a future legislature, stronger measures are needed.

The only approach so far that has succeeded in protecting tobacco

138. Esmé E. Deprez \& Paul Barrett, The Lawyer Who Beat Big Tobacco Takes on the Opioid Industry, BlOOMBERG BUSINESSWEeK (Oct. 5, 2017, 3:00 AM), https://www.bloomberg.com/ news/features/2017-10-05/the-lawyer-who-beat-big-tobacco-takes-on-the-opioid-industry.

139. The states and cities bringing these lawsuits would presumably prefer that they - rather than some national foundation — get to decide how the resulting proceeds are spent.

140. And unlike the American Legacy Foundation, it would be preferable if such a foundation were funded (or endowed) in perpetuity.

141. The foundation set up in Ohio was a government entity, which is a key difference with the non-governmental foundation established in Mississippi. 
settlement funds from diversion is a state constitutional amendment, as was used in Florida (though the Florida example also suggests the need to remain active in protecting funding even after such an amendment is approved). There are obvious reasons, though, why constitutional amendments have not been used more broadly to protect tobacco control funding. For one, they are expensive. The Florida campaign cost more than $\$ 5$ million in 2006; ${ }^{142}$ the price tag would be much higher today. The campaign for California's 2016 amendment to raise the cigarette tax cost more than $\$ 35$ million, and tobacco companies spent more than $\$ 70$ million to oppose it. ${ }^{143}$ Additionally, constitutional amendment elections are not easy to win, despite broad public support for using tobacco-related proceeds for public health. In 2002, for example, an effort to allocate the bulk of Michigan's MSA money to health care and tobacco prevention efforts was defeated by a 2-to-1 margin. ${ }^{144}$ More recently, the tobacco companies spent more than $\$ 17$ million (which equated to more than $\$ 66$ per vote) in 2018 to defeat a tobacco tax increase in Montana. ${ }^{145}$

In the opioid context, it is less clear what groups would bankroll an effort to ensure that litigation proceeds are used to address the epidemicand the many different parties involved (prevention groups, treatment groups, harm reduction groups, health care entities, insurers, law enforcement, etc.) may make it difficult to even come up with an agreedupon plan for how proceeds should be spent. ${ }^{146}$ At the same time, however, it is also less clear who the determined opposition would be. Unlike the tobacco companies, who have an ongoing interest in selling

142. BallotPedia, Florida Amendment 4, Use of Tobacco Settlement Funds (2006), https://ballotpedia.org/Florida_Amendment_4,_Use_of_Tobacco_Settlement_Funds_(2006) [https://perma.cc/L5WE-D3AR] (last visited Apr. 3, 2019).

143. BallotPedia, California Proposition 56, Tobacco Tax Increase (2016), https://ballotpedia.org/California_Proposition_56, Tobacco_Tax_Increase_(2016) [https://perma.cc/ R6MS-N7ZG] (last visited Apr. 3 , 2019).

144. Frank A. Sloan et al., States' Allocations of Funds from the Tobacco Master Settlement Agreement, 24 HeAlth AfF. 220, 222 (2005).

145. BallotPedia, Montana I-185, Extend Medicaid Expansion and Increase Tobacco Taxes Initiative (2018), https://ballotpedia.org/Montana_I-185, Extend_Medicaid_Expansion_and Increase_Tobacco_Taxes_Initiative_(2018) [https://perma.cc/N6Z4-VBWZ] (last visited Apr. 3 , 2019). This tax was proposed as an initiated statute, rather than as a constitutional amendment. Id.

146. For example, those involved in law enforcement may push for more money to be spent on law enforcement approaches, while public health advocates would prefer for money to be spent on prevention and treatment (and may view standard law enforcement approaches as counterproductive). In the tobacco context, the $\mathrm{CDC}$ has developed evidence-based best practices for state tobacco control programs, which have guided the most successful state programs and framed the approach pursued in ballot initiatives. Centers for Disease Control and Prevention, Best Practices for COMPREHENSIVE ToBACCO CONTROL Programs (2014). No similar guide yet exists for state-level programs to address the opioid epidemic (though the CDC has produced numerous publications that could inform aspects of such a program). 
more tobacco products (and hence in opposing effective tobacco control measures), pharmaceutical manufacturers and distributors are, for the most part, far more diversified and are already moving to develop alternatives to opioids that do not pose the same risk of addiction. ${ }^{147}$ They would be far less likely to actively oppose efforts to fund opioid treatment and prevention. ${ }^{148}$

Nonetheless, even in this context, constitutional amendment campaigns would not necessarily be easy to win. The recent defeat of Ohio Issue 1-designed, in part, to fund opioid treatment programs - was partially due to the opposition's argument that, whatever the merits of the policy under discussion, specific policy changes and spending decisions should not be written into the state's constitution. ${ }^{149}$ Moreover, as the use of ballot issues to undo or circumvent legislative decision-making has become more prevalent, legislatures in numerous states have sought to make it more difficult to pass constitutional amendments. ${ }^{150}$

Use of constitutional amendments, therefore, is a difficult and risky strategy. And indeed, only eighteen states allow for voters to directly initiate a constitutional amendment. ${ }^{151}$ Still, the experience of the MSA

147. Alex Keown, Increased Development of Non-Opioid Pain Treatments is Expected to Continue, BIOSPACE (June 29, 2018), https://www.biospace.com/article/increased-development-ofnon-opioid-pain-treatments-is-expected-to-continue/ [https://perma.cc/T5US-RXKG].

148. Indeed, Purdue Pharma, as the owner of the company that holds the patent for Buprenorphine (used to treat opioid dependence), could benefit from expanded treatment efforts. Mark Terry, In Negotiations of 1,000 Opioid Lawsuits, Purdue Pharma Offers Free Opioid Therapy, BIOSPACE (Sept. 12, 2018), https://www.biospace.com/article/-jcln-in-negotiations-of-1-000-opioidlawsuits-purdue-pharma-offers-free-opioid-therapy/ [https://perma.cc/G8AX-UGCP].

149. See, e.g., Opinion, Enquirer Endorsement: No On Issue 1, CINCINNATI ENQUIRER (Nov. 4, 2018, 7:09 AM), https://www.cincinnati.com/story/opinion/2018/11/04/enquirer-endorsement-noissue-1/1811742002/ [https://perma.cc/2CQK-8CKQ] ("[O]nce something is embedded in the constitution, as Issue 1 on Tuesday's ballot proposes, it is written in stone and can be very challenging and expensive to undo. That's why The Enquirer's editorial board is recommending that voters say NO to Issue 1.").

150. Alan Greenblatt, Lawmakers Eye Changes to Ballot Measures-Past and Future, GOVERNING (Jan. 16, 2019, 4:00 AM), http://www.governing.com/topics/politics/gov-lawmakersblock-ballot-measures.html [https://perma.cc/26SE-9V4W]. The tobacco industry has a history of working behind the scenes to make it more difficult to propose and adopt ballot issues. Elizabeth Laposata, Allison P. Kennedy \& Stanton A. Glantz, When Tobacco Targets Direct Democracy, 39 J. HEALTH POL., POL'Y \& L. 537 (2014).

151. BALlotPediA, Amending State Constitutions, https://ballotpedia.org/Amending state_constitutions [https://perma.cc/F53P-LGS8] (last visited Apr. 3, 2019). In nearly every state, the state legislature can refer a constitutional amendment to the ballot. Id. This may be another approach to consider, though it would likely be difficult to persuade legislatures to propose constitutional amendments that would limit their own power. As noted previously, a few states passed legislativelyreferred constitutional amendments in the wake of the MSA, and useful lessons can be learned from the experiences of these states. See, e.g., Randy Torrijos \& Stanton A. Glantz, Tobacco Control Policy Making in Montana 1979-2005: Falling Off the Horse at the Finish Line, UCSF CNTR. FOR TOBACCO CONTROL RES. AND ED. 56-61 (Nov. 1, 2005), https://cloudfront.escholarship.org/dist/prd 
suggests that this is a strategy worth considering where it is legally viable. Otherwise, public health advocates may expend enormous energy working to negotiate a plan for how settlement proceeds can be spent, only to see that agreed-upon framework (and newly-established programs) dissolve after a couple of years.

\section{CONCLUSION}

Former American Legacy Foundation CEO Cheryl Healton has warned against "Monday morning quarterback[ing]" the MSA, noting that "those who have critiqued the actual outcomes of the MSA were not participants in the settlement process and thus have little firsthand knowledge about what was possible." 152 That point has merit, but it does not excuse a failure to learn from the MSA's mistakes when planning for the future. The tragedy of the MSA is that it was a unique opportunity to build a sustainable tobacco control (or broader public health) infrastructure. With only $18 \%$ of the MSA revenues, every state could have funded its tobacco control program at CDC-recommended levels, with no other funding needed. ${ }^{153}$ Such a foundation would have put us on the road towards ending the nation's tobacco epidemic once and for all. Instead, the MSA produced a short-term increase in tobacco control funding, but the vast majority of MSA funds were soon diverted to other purposes.

Like the MSA, a global opioid settlement agreement may be a oncein-a-generation opportunity to secure funds needed to rebuild the country's decimated public health infrastructure. But time may be quickly running out to plan for such a settlement before it occurs, and the much larger number of jurisdictions involved makes planning much more complicated. ${ }^{154}$ This article has suggested some possible mechanisms through which those pursing the litigation could follow through on their expressed intention to ensure that funds are used (over the long term) for public health and opioid treatment. If they fail to do so, states and localities should explore their own options for permanently dedicating a

\footnotetext{
/content/qt2rj5f9cr/qt2rj5f9cr.pdf?t=lnp4eb [https://perma.cc/VZ3D-TJ4G] (detailing how Montana's constitutional amendment created a trust fund for health care and tobacco control programs, but because the amendment did not require any minimum level of appropriation for tobacco control, the state's program remained underfunded).

152. Healton, supra note 128 , at $12 \mathrm{~S}$.

153. Id. at $13 \mathrm{~S}$.

154. Further complicating the planning is the fact that while we generally know what works to reduce tobacco use, the opioid epidemic is much more of a "wicked problem" where the solutions are far less clear. See Jonathan C. Lee, The Opioid Crisis is a Wicked Problem, 27 AM. J. ON ADDICTIONS 51 (2018).
} 
significant portion of the funds to addressing the current public health crisis and preventing the next one. The time to be making such fallback plans is now. 